ZOOLOGIA 32 (3): 195-200, June 2015

http://dx.doi.org/10.1590/S1984-46702015000300003

\title{
Annual male reproductive activity and stages of the seminiferous epithelium cycle of the large fruit-eating Artibeus lituratus (Chiroptera: Phyllostomidae)
}

\author{
Alice A. Notini ${ }^{1}$, Talita O. Farias ${ }^{1}$, Sônia A. Talamoni ${ }^{1{ }^{*}}{ }^{*}$ Hugo P. Godinho ${ }^{1}$ \\ 'Programa de Pós-graduação em Zoologia de Vertebrados, Departamento de Ciências Biológicas, Pontifícia Universidade \\ Católica de Minas Gerais, Avenida Dom José Gaspar, 500, 30535-610, Belo Horizonte, Minas Gerais, Brazil. \\ “Corresponding author. E-mail: talamoni@pucminas.br
}

\begin{abstract}
The large fruit-eating phyllostomid bat, Artibeus lituratus (Olfers, 1818), forearm 69-75 mm, body mass 66$82 \mathrm{~g}$, has a diversified geographic distribution in the Neotropical region. Therefore it is subjected to different climatic conditions that affect its reproduction, leading to different reproductive strategies such as continuous reproduction, seasonal monoestry or seasonal bimodal polyestry. In this study we used morphometric and histological methods to analyze the annual reproductive activity of $A$. lituratus males in a population living in the Atlantic Forest, Southeastern Brazil. Testis mass, epididymis mass, gonadosomatic index, seminiferous tubule diameter, and Leydig cell nucleus diameter showed no significant differences $(p>0.05)$ in the two seasons (wet: October to March; dry: April to September). Additionally, the cauda epididymis was packed with sperm throughout the period of study. Our data indicate that in this population spermatogenic activity was continuous throughout the year. Slight variations in accumulated frequency of pre-meiotic, meiotic and post-meiotic stages of the seminiferous epithelium cycle were observed when compared to other bat species, probably due to species-specific characteristics.
\end{abstract}

KEY WORDS. Morphometry; Neotropical bat; seminiferous epithelium; spermatogenesis; reproduction.

The large fruit-eating phyllostomid bat, Artibeus lituratus (Olfers, 1818), is widely distributed in the Neotropical region; it occurs from Central Mexico, the Lesser Antilles, Trinidad and Tobago, south to North-central Argentina. It occupies a variety of habitats from the sea level to at least $2,620 \mathrm{~m}$ (MARQues-Aguiar 2007). This bat features a large body (mass 66$82 \mathrm{~g}$ ), with forearm length exceeding $70 \mathrm{~mm}$ (VIzotTo \& TADDEI 1973), white facial stripes, and brown body color, although grayish individuals occur in some regions (ReIs et al. 2007).

Differences in the reproductive traits of A. lituratus, reported by various authors, have been attributed to its wide area of occurrence. A bimodal pattern of reproduction with a minor birth peak during the dry season and a main birth peak in the rainy season have been observed in Panama and Costa Rica (Fleming et al. 1972), and Brazil (ReIs 1989). Based on analysis of seasonal testis activity in Southeastern Brazil, OLIveira et al. (2009) reported that the reproductive period of this bat coincides with the rainy season, and is followed by testicular regression before a new cycle of testicular recrudescence. However, in other studies, males have been considered fertile year-round, since they exhibit continuous spermatogenesis (Tamsitt \& Valdivieso 1963, Duarte \& Talamoni 2010).

The well-defined rainy season of Southeastern Brazil is characterized by abundant rainfall associated with high tem- peratures and humidity (SÁ JúNIOR et al. 2012). Rains are essential for seed germination and for the fruits that large fruit-eating bats depend on. The dry season is characterized by shortage in rainfall, flowers and food. Despite apparently unfavorable environmental conditions, females of some species reproduce during the dry season and the birth of their offspring coincides with fruiting in the next rainy season (RACEY 1982).

In mammals, germ cells are arranged in typical cell associations known as stages (França et al. 2005, Hess \& FrançA 2007). These stages follow one another in time, characterizing the seminiferous epithelium cycle. Based on the tubular morphology method, eight stages have been described for the seminiferous epithelium cycle of mammals (BERNDTSON 1977 França \& Russell 1998), including Neotropical bats (BeguelinI et al. 2009, Oliveira et al. 2009, Morais et al. 2013).

In this paper, we evaluated data obtained on testis and epididymis mass, gonadosomatic index, diameter of seminiferous tubules, and Leydig cell nucleus diameter in order to determine whether there are variations in the annual reproductive activity of large fruit-eating bat males. The data were grouped into rainy and dry seasons, since these are two major seasonal variables that affect bat reproduction in the Neotropics (RACEY \& ENTWISTLE 2000). We registered the occurrence of sperm in the cauda epididymis during the period of study. Finally, we

2015 | Sociedade Brasileira de Zoologia | www.sbzoologia.org.br | www.scielo.br/zool All content of the journal, except where identified, is licensed under a Creative Commons attribution-type BY-NC. 
characterized the stages of the seminiferous epithelium cycle and their relative frequency of occurrence, which were then analyzed and compared with respect to the rainy-dry seasons.

\section{MATERIAL AND METHODS}

The study was conducted in the Special Protection Area of Fechos (SPA Fechos), an area with 1,076 ha, 1,400 m above sea level in the state of Minas Gerais, Southeastern Brazil $\left(20^{\circ} 04^{\prime} \mathrm{S}\right.$, $\left.43^{\circ} 57^{\prime} \mathrm{W}\right)$. SPA Fechos consists of semideciduous forest fragments, typical of the Atlantic Forest. As in the remaining of Southeastern Brazil, SPA Fechos is subject to a well defined rainy season (from October to March) and a dry season (from April to September) (SÁ JúNIOR et al. 2012). Rainfall in the area during the period of study was $1,457.8 \mathrm{~mm}$. November and January had the highest rainfall values, $321.7 \mathrm{~mm}$ and $276.8 \mathrm{~mm}$, respectively. During the same period, the monthly average temperatures ranged from 10.8 to $29.2^{\circ} \mathrm{C}$. December to March was the hottest period, with mean temperature $21.3^{\circ} \mathrm{C}$, and July to September was the coolest period, with mean temperature $16.9^{\circ} \mathrm{C}$.

The bats were captured monthly on two consecutive nights from December 2001 to January 2003, using mist nets left in the forest from 18:00 to $24: 00 \mathrm{~h}$, following the procedures described in Duarte \& TAlamoni (2010). Thirty-three adult males were captured and killed with an overdose of ether followed by cervical dislocation. They were categorized as adults when they displayed ossified epiphyseal plates in the metacarpal and phalangeal bones (ANTHONY 1988). At the time of capture, the body mass and position of the testis in relation to the scrotum were registered.

Scrotal testes and respective epididymides were removed and weighed. The gonadosomatic index (GSI = mass of testis $\mathrm{x}$ 200/body mass) was calculated for each bat. Since the left and right testis and the epididymis did not present significant mass differences $(p>0.05)$, the left testis and epididymis were cut into fragments and fixed in Bouin solution for 8-12 hours. The fragments were subjected to routine histological techniques for embedding in plastic resin and $5 \mu \mathrm{m}$-thick histological sections stained in toluidine blue were obtained. Two-hundred near circular cross-sections of seminiferous tubules from 24 bats were digitally photographed in an optical microscope and had their diameter measured using Image J (RASBAnd 2012). They were also used to categorize the stages of the seminiferous epithelium cycle, using the method of tubular morphology (CLERmont 1972, Berndtson 1977, França \& Godinho 2003), based on the following characteristics: shape of spermatid nuclei, occurrence of meiotic divisions, and position of spermatids in the seminiferous epithelium. We also measured the diameter of 10 Leydig cell nuclei close to the seminiferous tubules in stage 1 of the seminiferous epithelium cycle from each of 15 bats.

Bat capture and handling were conducted according to guidelines of the Brazilian National Council for the Control of Animal Experimentation (CONCEA), which are aligned with standard international norms. This study was carried out under license (\# 206/2001) granted by the Brazilian Institute of Natural Environment and Renewable Resources (IBAMA). The bats are deposited in the collection of the Pontifical Catholic University of Minas Gerais, Belo Horizonte, MG, Brazil.

Data are presented as mean \pm SD (standard deviation). They were initially tested for normality. Variations in testis parameters obtained in the rainy and dry seasons were evaluated by the Student's t test $(\mathrm{p}<0.05)$. Since GSI did not present normal distribution, the non-parametric Mann-Whitney test was used. The relative frequencies of the stages of the seminiferous epithelium cycle were subjected to chi-square test $\left(\chi^{2}\right)$ for comparison between the rainy and the dry seasons (SOKAL \& RoHLF 1995).

\section{RESULTS}

\section{Corporal and testis parameters}

We registered no statistically significant variation in the parameters analyzed between the rainy and the dry seasons (Table 1). All captured bats had functional spermatogenic testis and cauda epididymis packed with spermatozoa (Fig. 1).

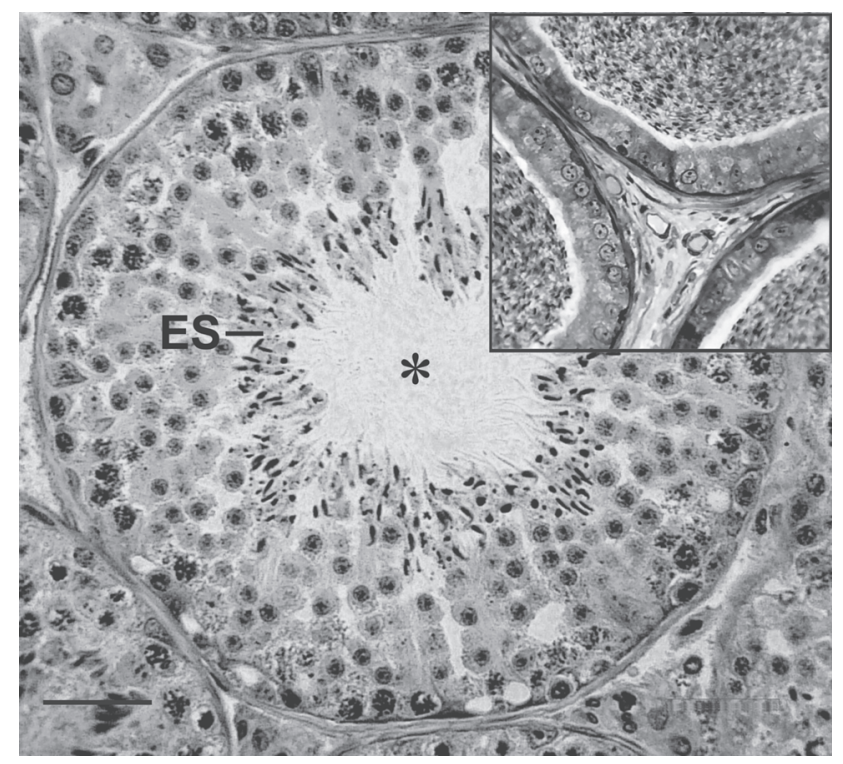

Figure 1. Transverse section of seminiferous tubule of $A$. lituratus in activity (diameter, $194 \pm 8 \mu \mathrm{m}$ ). Note elongated spermatids (ES) and abundant spermatozoa in the lumen $\left(^{*}\right)$. Insert shows transverse section of cauda epididymis packed with spermatozoa. H-E stain. Scale bars: $69 \mu \mathrm{m}$.

\section{Stages of the seminiferous epithelium cycle}

We characterized eight stages of the seminiferous epithelium cycle (SEC) of the large fruit-eating bat (Figs. 2-9) according to the tubular morphology method. Most cross-sections 
Table 1. Mean values ( \pm 1 Standard Deviation) of corporal mass $(C M, g)$, testis mass $(T M, g)$, epididymis mass (EM, g), gonadosomatic index (GSI), diameter of the seminiferous tubules (DST, $\mu \mathrm{m}$ ) and diameter of the Leydig cell nucleus (DLC, $\mu \mathrm{m}$ ) of the large fruit-eating bat in rainy and dry seasons (respective sample sizes in parenthesis) of December 2001 to January 2003.

\begin{tabular}{lcccccc}
\hline \multicolumn{1}{c}{ Season } & $\mathrm{CM}(13,15)$ & $\mathrm{TM}(13,15)$ & $\mathrm{EM}(11,12)$ & $\mathrm{GSI}(13,15)$ & $\mathrm{DST}(12,12)$ & $\mathrm{DLC}(8,8)$ \\
\hline Rainy & $67.3 \pm 4.6$ & $0.13 \pm 0.05$ & $0.02 \pm 0.01$ & $0.37 \pm 0.15$ & $197 \pm 10$ & $6.37 \pm 0.51$ \\
Dry & $66.8 \pm 6.0$ & $0.12 \pm 0.07$ & $0.03 \pm 0.02$ & $0.36 \pm 0.20$ & $190 \pm 5$ & $6.37 \pm 0.51$ \\
Student's t-test & 0.27 & 0.24 & -0.36 & $83.5^{*}$ & 0.72 & 0.00 \\
Significance level & $\mathrm{ns}$ & $\mathrm{ns}$ & $\mathrm{ns}$ & $\mathrm{ns}$ & $\mathrm{ns}$ & $\mathrm{ns}$ \\
\hline
\end{tabular}

$\mathrm{ns}=\mathrm{p}>0.05 ;{ }^{*}=$ Mann-Whitney test.

of seminiferous tubules contained cell associations of only one stage. On rare occasions when two stages were present only the one occupying the largest cross-section area was registered. Composition and spatial arrangement of cells in each stage of the SEC are presented below.

Stage 1 was characterized by the presence of one generation of round spermatids in the upper part of the seminiferous epithelium bordering the lumen (R, Fig. 2). Two generations of primary spermatocytes were registered. The most advanced one was pachytene spermatocytes placed deeper in the seminiferous epithelium and close to round spermatids (P, Fig. 2), whereas preleptotene spermatocytes (Pl, Fig. 2) were located next to the basement membrane. Type-A spermatogonia (A, Fig. 2) rested on the basement membrane. Sertoli cell nuclei (S, Fig. 2) were situated close to basement membrane in this stage as well as in the remaining stages of the SEC. Leydig cells (Ly, Fig. 2) occupied the intertubular space.

Stage 2. Spermatids (E, Fig. 3) in process of nuclear elongation characterized this stage. It also exhibited type-A spermatogonia (not shown in Fig. 3) resting on basement membrane, as well leptotene spermatocytes (L, Fig. 3) and one or two layers of pachytene spermatocytes (P, Fig. 3). Sertoli cell nuclei (S, Fig. 3) and Leydig cells (Ly, Fig. 3) showed characteristics similar to those of the previous stage.

Stage 3. Elongated spermatid nuclei were arranged in bundles (ES, Fig. 4) and occupied the intermediate portion of the seminiferous epithelium. Two generations of primary spermatocytes were still seen in this stage: one generation at zygotene (Z, Fig. 4), and the other at pachytene or diplotene (D, Fig. 4). Type-A spermatogonia and Sertoli cell nuclei (not shown in Fig. 4) resting on basement membrane completed the cell composition of this stage.

Stage 4. The presence of meiotic divisions (M, Fig. 5) characterized this stage: primary spermatocytes divided into secondary spermatocytes $(\mathrm{D} / \mathrm{II})$ which then divided to give rise to round spermatids. Zygotene (Z, Fig. 5) and diplotene spermatocytes (not shown in Fig. 5), and bundles of elongated spermatid nuclei (ES, Fig. 5) in the upper region of the seminiferous epithelium were also registered (Fig. 5). Sertoli cell nuclei (S, Fig. 5) and type A-spermatogonia (not shown in Fig. 5) had similar position and morphology to those of previous stages.

Stage 5 was characterized by the presence of newly- formed round spermatids (R, Fig. 6), and by an older generation of elongated spermatids with nuclei arranged in bundles (ES, Fig. 6). Spermatocytes at the transition zygotene/pachytene (Z/P, Fig. 6) were also observed. Sertoli cell nuclei (S, Fig. 6) and type-A spermatogonia (not indicated in this Fig. 6) had similar morphology and occupied same positions as in previous stages.

Stage 6. Most bundles of elongated spermatid nuclei were now next to the lumen of the seminiferous epithelium, whereas the remaining ones were located deeper in the seminiferous epithelium. Type-B spermatogonia (not indicated in this Fig. 7) were first seen in this stage along with type-A spermatogonia (A, Fig. 7). Spermatocytes at pachytene (P, Fig. 7) and layers of round spermatids (R, Fig. 7) were also present.

Stage 7. Loosen bundles of elongated spermatid nuclei (ES, Fig. 8) next to the lumen of the seminiferous tubule characterized this stage. Various layers of round spermatids (R, Fig. 8 ) were registered interspersed among pachytene spermatocytes (P, Fig. 8). Type-A and type-B spermatogonia (not shown in this Fig. 8), and Sertoli cell nuclei (S, Fig. 8) appeared close to basement membrane.

Stage 8 . This stage was characterized by elongated spermatid nuclei (ES, Fig. 9) bordering the seminiferous epithelium. Several residual bodies (RB, Fig. 9) near elongated spermatid nuclei also characterized this stage. Type-A and typeB spermatogonia (not shown in this Fig. 9) rested on basement membrane. One layer of preleptotene spermatocytes (Pl, Fig. 9) which originated from type B spermatogonia, pachytene spermatocytes (P, Fig. 9), and round spermatids (R, Fig. 9) were also present.

\section{Frequency of stages of the seminiferous epithelium cycle}

The relative frequencies of stages of the SEC are shown in Fig. 10; no significant differences were found between stage frequencies in the rainy and the dry seasons $\left(\chi^{2}=4.307, \mathrm{p}>\right.$ $0.05, \mathrm{n}=8$ and 8 , respectively). Stages 1 and 7 were the most frequent, and stages 2 and 5 the least frequent. The accumulated relative frequency of pre-meiotic stages (stages 1 to 3 ) was $40 \pm 7.7 \%$ and that of post-meiotic stages (stages 5-8) was $49 \pm 5.6 \%$. The meiotic stage, corresponding to stage 4 , was 12 $\pm 4.2 \%$. 


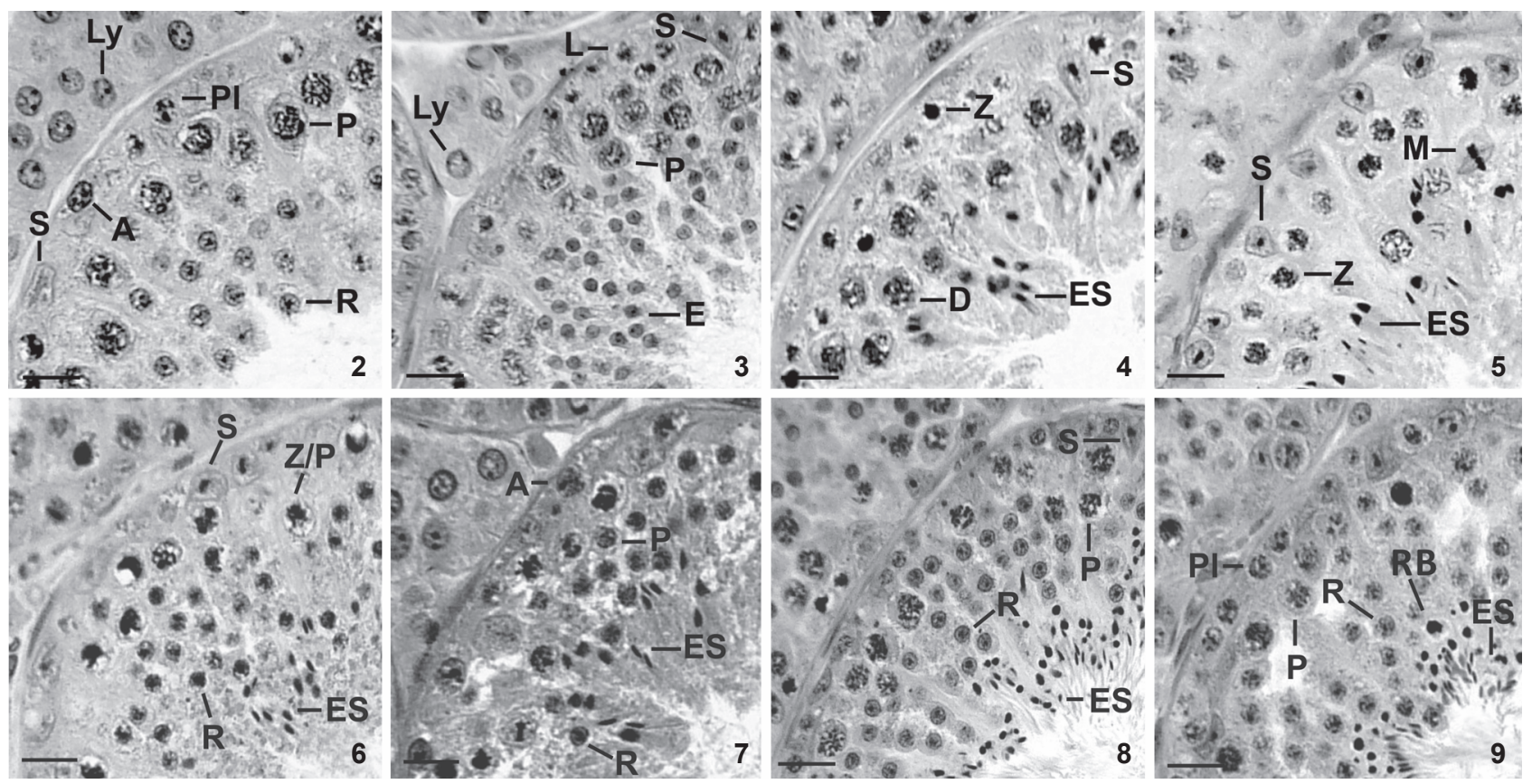

Figures 2-9. Stages 1-4 of the seminiferous epithelium cycle of the large fruit-eating bat based on the tubular morphology method. (2) Stage 1 contains Sertoli cell (S), type-A spermatogonium (A), preleptotene primary spermatocyte (PI), pachytene primary spermatocyte $(P)$, round spermatid $(R)$, besides Leydig cells (Ly) in the intertubular space. (3) Stage 2 presents Sertoli cell (S), leptotene primary spermatocyte $(L)$, pachytene primary spermatocyte $(P)$ and elongating spermatid (E), besides Leydig cell (Ly). (4) Stage 3 contains Sertoli cell (S), zygotene primary spermatocyte (Z), diplotene primary spermatocyte (D) and elongated spermatid (ES). (5) Stage 4 contains Sertoli cell (S), zygotene primary spermatocyte (Z), diplotene primary spermatocyte (D), meiotic figure (M) and elongated spermatid (ES). (6) Stage 5 contains Sertoli cell (S), zygotene/pachytene primary spermatocyte (Z/P), round spermatid (R) and elongated spermatid (ES). (7) Stage 6 presents type-A spermatogonium (A), pachytene primary spermatocyte (P), round spermatid (R) and elongated spermatid (ES). (8) Stage 7 presents Sertoli cell $(S)$, pachytene spermatocyte (P), round spermatid (R) and elongated spermatid (ES). (9) Stage 8 contains preleptotene primary spermatocyte (PI), pachytene spermatocyte (P), round spermatid (R), elongated spermatid (ES) and residual bodies (RB). H-E stain. Scale bars: $61 \mu \mathrm{m}$.

\section{DISCUSSION}

None of the morphometric parameters of the large fruiteating bat, i.e. testis and epididymis masses, seminiferous tubule diameter, and diameter of Leydig cell nucleus changed significantly between the rainy and the dry seasons. This confirms that continuous spermatogenic activity is taking place, as first described by Duarte \& Talamoni (2010) for this species in the Atlantic Forest, Southeastern Brazil. The cauda epididymis packed with spermatozoa throughout the study period was also evidence of male continuous reproductive capacity. Testis regression and recrudescence during the annual reproductive cycle (Oliveira et al. 2009) were not registered in our study. A recent study on the reproductive cycle of the congeneric Artibeus planirostris (Spix, 1823) in Brazil also indicates continuous spermatogenic activity based on constant production of spermatozoa and their retention/storage in the cauda epididymis (Beguelini et al. 2013). Similar results have been shown for other phyllostomid fruit-eating bats, i.e. Artibeus jamaicensis Leach, 1821, Artibeus intermedius Allen, 1897, and Dermanura phaeotis (Miller, 1902), from Mexico, in which males present reproductive activity throughout the year while females tend to be polyestric (MonTiel et al. 2011).

The organization of large fruit-eating bat colonies into a harem system (MoRrison 1980), also reported for A. planirostris (BEGUELINI et al. 2013), results in polygynous behavior (WILSON 1979). Mammals exhibiting this reproductive behavior have usually low testis mass (KenAgy \& TROMBULAK 1986) which would explain the low GSI value recorded in the present study. Contrarily, other microchiropterans organized in large social groups face increased risk of sperm competition, which results in greater investment in spermatogenesis (HOSKEN 1997), and consequently larger GSI. BEGUELINI et al. (2013) showed that GSI values also accompany the two pronounced annual peaks of spermatogenesis in A. planirostris. According to latter authors, despite the annual continuous spermatogenic production, GSI 


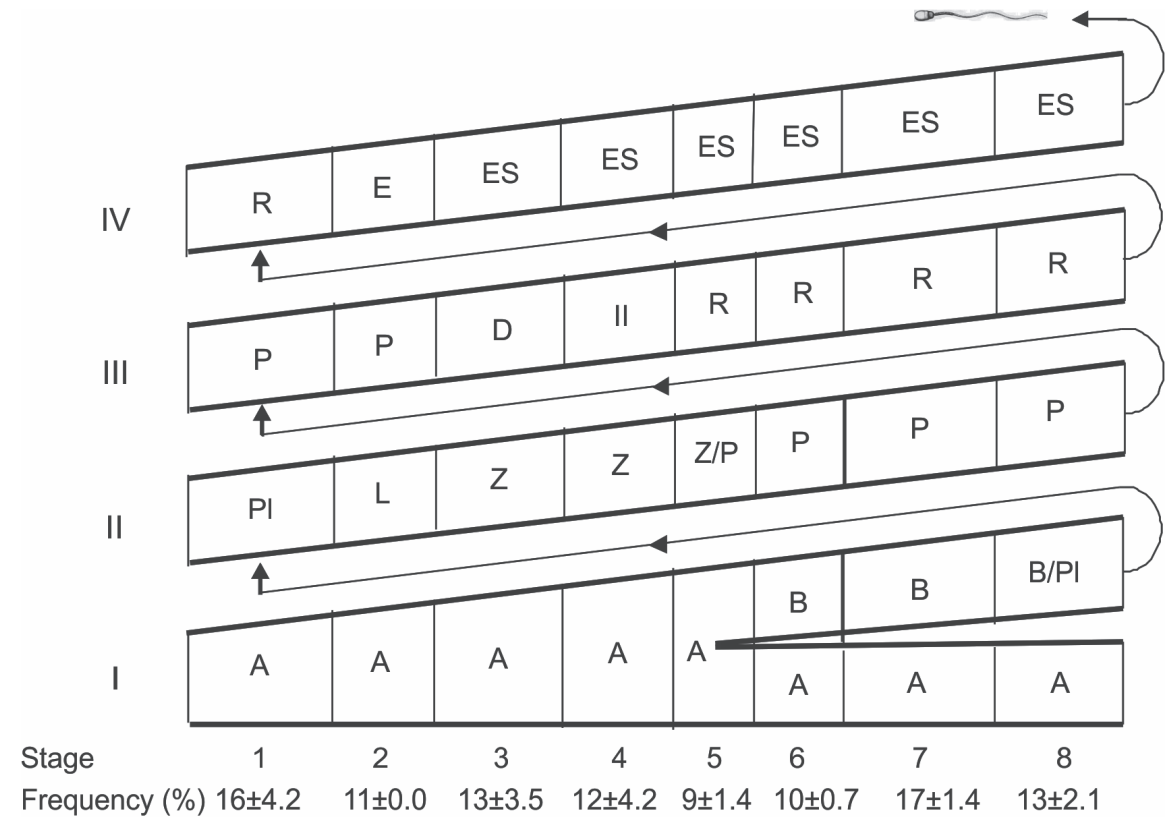

Figure 10. Cell composition and frequency (\%) of the stages (1-8) of the cycle (I-IV) of the seminiferous epithelium of the large fruit-eating bat; column width, representing each stage, is proportional to its frequency. (A) Type-A spermatogonium, (B) type-B spermatogonium, (PI) primary spermatocytes in preleptotene, $(\mathrm{L})$ primary spermatocytes in leptotene, $(Z)$ primary spermatocytes in zygotene, $(\mathrm{P})$ primary spermatocytes in pachytene, (D) primary spermatocytes in diplotene, (II) secondary spermatocytes, (R) round spermatids, (E) elongating spermatids, (ES) elongated spermatids.

peaks possibly express a spermatic production needed to synchronize with the bimodal reproductive cycle of females. Thus, monoestry categorization, as suggested for this bat population (DuARTE \& TALAMONi 2010), or bimodal polyestry, as observed for other phyllostomids, should be only ascribed after evaluating the female's reproductive cycle.

Three basic types of mammalian spermatogonium recognized under routine microscopy, namely type-A, intermediate, and type-B, are also registered in bats (Beguelini et al. 2009, Oliveira et al. 2009). However, most likely due to technical reasons, we did not identify intermediate types of spermatogonium in the large fruit-eating bats of the present study.

As in non-primate mammals (LEAL \& FrançA 2006), crosssections of seminiferous tubules of large fruit-eating bats show cell associations belonging to a single stage of the SEC. The eight stages of the SEC previously described for this species (BEGUelini et al. 2009) have been confirmed in the present study. In general, the cellular composition of these stages is similar to that of other mammals, including other Neotropical phyllostomids (Beguelini et al. 2009, Oliveira et al. 2009, Morais et al. 2013). One exception is the vespertilionid Myotis nigricans, in which different cell associations occur in cross-sections of the seminiferous tubule (Beguelini et al. 2009). The species-constant relative frequencies of stages of the SEC (Hess \& FRANÇA 2007) were confirmed by our study and, similarly to the re- sults of a study on Sturnira lilium (E. Geoffroy, 1810) (MoraIs et al. 2013), no differences were detected between the rainy and the dry seasons. The smaller accumulated frequency of premeiotic stages with respect to post-meiotic stages, obtained in the present study, was similar to the results of BeGUeLINI (2009).

In conclusion, the spermatogenic activity of large fruiteating bats from the Atlantic Forest in Southeastern Brazil was continuous throughout rainy and dry seasons. Cell associations and the relative frequency of the eight stages of the seminiferous epithelium cycle, categorized by the tubular morphology method, presented no significant differences between the rainy and the dry seasons.

\section{ACKNOWLEDGMENTS}

We thank Fundação de Amparo à Pesquisa do Estado de Minas Gerais (FAPEMIG) and Fundo de Incentivo à Pesquisa (FIP PUC Minas) for funding the project, and FIP PUC Minas for scholarships granted to A.A.N. and T.O.F. We also thank Ana Paula G. Duarte for participation in collecting data, to the Brazilian Institute of Natural Environment and Renewable Resources (IBAMA) for providing the license to capture the animals and Companhia de Saneamento do Estado de Minas Gerais (COPASA) for permission to work in the Special Protection Area of Fechos. 


\section{LITERATURE CITED}

Anthony ELP (1988) Age determination in bats, p. 47-57. In: Kunz TH (Ed). Ecological and behavioral methods for the study of bats. Washington, Smithsonian Institution Press.

Beguelini MR, Moreira PRL, Faria KC, Marchesin SRC, MorielleVersute E (2009) Morphological characterization of the testicular cells and seminiferous epithelium cycle in six species of Neotropical bats. Journal of Morphology 270: 943-953. doi: 10.1002/jmor.10731

Beguelini MR, Puga CCL, Taboga SR, Morielle-Versute E (2013) Annual reproductive cycle of males of the flat-faced fruiteating bat, Artibeus planirostris (Chiroptera: Phyllostomidae). General Comparative Endocrinology 185: 80-89. doi: 10.1016/j.ygcen.2012.12.009

Berndtson WE (1977) Methods for quantifying mammalian spermatogenesis: a review. Journal of Animal Science 44: 818-833. doi: 10.2134/jas1977.445818x

Clermont Y (1972) Kinetics of spermatogenesis in mammals: seminiferous epithelium cycle and spermatogonial renewal. Physiological Reviews 52: 198-236.

Duarte APG, TaLAmoni SA (2010) Reproduction of the large fruiteating bat Artibeus lituratus (Chiroptera: Phyllostomidae) in a Brazilian Atlantic forest area. Mammalian Biology 75: 320-325. doi: 10.1016/j.mambio.2009.04.004

Fleming TH, Hooper ET, WiLson DE (1972) Three Central American bat communities: structure, reproductive cycles, and movement patterns. Ecology 53: 555-569. doi: 10.2307/1934771

FRANÇA LR, GODINHO CL (2003) Testis morphometry, seminiferous epithelium cycle length, and daily sperm production in domestic cats (Felis catus). Biology of Reproduction 68: 1554-1561. doi: 10.1095/biolreprod.102.010652

FranÇA LR, Russell LD (1998) The testis of domestic animals, p. 197219. In: Martínez-García F, Regadera J (Eds.). Male reproduction, a multidisciplinary overview. Madrid, Churchill Livingstone.

França LR, Avelar GF, Almeida FFL (2005) Spermatogenesis and sperm transit through the epididymis in mammals with emphasis on pigs. Theriogenology 63: 300-318. doi: 10.1016/j.theriogenology.2004.09.014

Hess RA, França LR (2007) Spermatogenesis and cycle of the seminiferous epithelium, p. 1-15. In: Cheng CY (Ed.). Molecular mechanisms in spermatogenesis. Urbana, Landes Bioscience, Springer Science.

Hosken DJ (1997) Sperm competition in bats. Proceedings of the Royal Society of London B: Biological Sciences 264: 385-392. doi: 10.1098/rspb.1997.0055

Kenagy GJ, Trombulak SC (1986) Size and function of mammalian testis in relation to body size. Journal of Mammalogy 67: 1-22. doi: $10.2307 / 1380997$

Leal MC, França LR (2006) The seminiferous epithelium cycle length in the black tufted-ear marmoset (Callithrix penicillata) is similar to humans. Biology of Reproduction 74: 616-624. doi: 10.1095/biolreprod.105.048074
Marques-Aguiar SA (2007) Genus Artibeus Leach 1821, p. $301-$ 321. In: GaRdNer AL (Ed.). Mammals of South America. Marsupials, Xenarthrans, Shrews, and Bats. Chicago, University of Chicago Press.

Montiel S, Estrada A, Leon P (2011) Reproductive seasonality of fruiteating bats in northwestern Yucatan, Mexico. Acta Chiropterologica 13: 139-145. doi: 10.3161/150811011X578688

Morais DB, Paula TAR, Barros MS, Balarini MK, Freitas MBD, MatTA SLP (2013) Stages and duration of the seminiferous epithelium cycle in the bat Sturnira lilium. Journal of Anatomy 222: 372-379. doi: 10.1111/joa.12016

Morrison, D.W. 1980. Foraging and day-roosting dynamics of canopy fruit-bats in Panama. Journal of Mammalogy 61: 20-29. doi: $10.2307 / 1379953$

Oliveira RL, Oliveira AG, Mahecha GaB, Nogueira JC, Oliveira CA (2009) Distribution of estrogen receptors (Era and Erb) and androgen receptor in the testis of big fruit-eating bat Artibeus lituratus is cell-and stage-specific and increases during gonadal regression. General and Comparative Endocrinology 161: 283-292. doi: 10.1016/j.ygcen.2009.01.019

RACEY PA (1982) Ecology of bat reproduction, p. 57-104. In: KunZ TH (Ed.) Ecology of bats. New York, Plenum Press.

Racey PA, Entwistle AC (2000) Life-history and reproductive strategies of bats, p. 363-414. In: CRichton E, KRUtzsch P (Eds.). Reproductive biology of bats. San Diego, Academic Press.

RASBAND, W.S. 2012 Image J. Bethesda, U.S. National Institutes of Health. Available online at: http://imagej.nih.gov/ij [Accessed: 03/07/2012]

ReIS SF (1989) Reproductive biology of Artibeus lituratus (Olfers, 1818) (Chiroptera: Phyllostomidae). Revista Brasileira de Biologia 49: 369-372.

Reis NR, AL Peracchi, WA Pedro, Lima IP (2007) Morcegos do Brasil. Londrina, Editora da Universidade de Londrina.

Sá Júnior A, Carvalho LG, Silva FF, Alves MC (2012) Application of the Köppen classification of climatic zoning in the state of Minas Gerais, Brazil. Theoretical and Applied Climatology 108: 1-7. doi: 10.1007/s00704-011-0507-8

Sokal RR, Rohlf FJ (1995) Biometry: the principles and practice of statistics in biological research. New York, WH Freeman and Co., 3rd ed.

Tamsitt JR, Valdivieso D (1963) Reproductive cycle of the big fruit-eating bat, Artibeus lituratus Olfers. Nature 198: 104.

Vizotto LD, TAdDei VA (1973) Chave para determinação de quirópteros brasileiros. Boletim de Ciências da Faculdade de Filosofia, Ciências e Letras, São José do Rio Preto: 1-72.

WILSON DE (1979) Reproductive patterns, p. 317-378. In: BAKER RJ, JONES JR JK, CARTER DC (Eds.). Biology of bats of the world. Family Phyllostomidae. Lubbock, Texas Tech University Press Special Publications of Museum Texas Tech University, Part 3.

Submitted: 27 January 2015

Received in revised form: 2 May 2015

Accepted: 1 June 2015

Editorial responsibility: Carolina Arruda Freire 